\title{
Cell Wall Analysis of Gardnerella vaginalis (Haemophilus vaginalis)
}

\author{
J. J. HARPER AND G. H. G. DAVIS \\ Department of Microbiology, University of Queensland, St. Lucia, Brisbane, Australia
}

\begin{abstract}
Thin-layer chromatography was used to examine the amino acid and carbohydrate composition of the cell wall of the type strain of Gardnerella vaginalis and 11 clinical isolates. All strains contained alanine, glutamic acid, glycine, lysine, glucose, galactose, and another sugar tentatively identified as 6-deoxytalose. The amino acid composition of $G$. vaginalis cell walls was found to be like that of a gram-positive bacterium.
\end{abstract}

Leopold (15) reported the isolation of a small gram-negative pleomorphic rod from urine and from cervical swabs. Gardner and Dukes (8) isolated the bacterium from cases of vaginitis and subsequently named it Haemophilus vaginalis (9). Several features of the organism differed from those required for Haemophilus species, and it was thus renamed Corynebacterium vaginale (28). Its cell wall composition appeared to differ, however, from that of true Corynebacterium species (25). Relationships with several other genera were suggested $(1,21)$, and controversy continued over whether its characteristics were more like those of a gram-positive or a gram-negative bacterium $(3,4,13,21,26)$.

Several authors suggested that the bacterium called $H$. vaginalis should be placed in a new genus $(7,16,19)$, and in 1980 , Greenwood and Pickett proposed that the bacterium be reclassified in the genus Gardnerella as $G$. vaginalis (10). Piot et al. (20) carried out a numerical taxonomy study of 55 strains of $G$. vaginalis and 61 reference strains. The results supported the creation of a new genus for the organism as proposed by Greenwood and Pickett (10). Greenwood and Pickett defined $G$. vaginalis as a gram-negative to gram-variable organism. They reported that, although the cell wall morphology of $G$. vaginalis did not appear like that of a typical gram-negative bacterium, it did more closely resemble that of a gram-negative than a gram-positive organism, and they concluded that, as a result of the unusual cell wall of the organism, the genus Gardnerella was not presently assignable to a family.

In this paper we present data from analysis of cell wall amino acids and carbohydrates of $G$. vaginalis which show that the amino acid composition of $G$. vaginalis cell walls is that of a gram-positive bacterium.

\section{MATERIALS AND METHODS}

Bacterial strains. The $G$. vaginalis strains used in this study (see Table 1) are designated by the numbers used in the University of Queensland Department of Microbiology (UQM). Strain UQM1258 was obtained from the National Collection of Type Cultures as NCTC 10287; all other strains were freshly isolated from vaginal specimens. G. vaginalis isolates were identified by the cultural and physiological characteristics recommended by Dunkelberg et al. (6).

Growth of strains. Bacteria were grown for $48 \mathrm{~h}$ in static, 1-liter peptone-starch-dextrose (6) broth cultures, centrifuged, washed, dried with ethanol, and stored in dry powder form at $4^{\circ} \mathrm{C}$.

Cell wall amino acid analysis. Fully hydrolyzed cell wall material was prepared from approximately $10 \mathrm{mg}$ (dry weight) of cells by the hot trichloroacetic acidtrypsin rapid-screening method of Schleifer and Kandler (22). Chromatography of amino acids was carried out with the two-dimensional thin-layer chromatography system described by Harper and Davis (12).

Analysis of cell wall carbohydrates. The methods of Staneck and Roberts (23) were used to determine the carbohydrate composition of the cell walls. The solvent chloroform-acetic acid-water (30:35:5, vol/vol) described by Haer (11) was also used for some analyses.

\section{RESULTS}

The results of amino acid analyses are given in Table 1. The serine and aspartic acid spots observed in UQM strains $1851,1852,1853,1857$, 1858,1859 , and 1860 all appeared to be of lesser intensity than the alanine, glutamic acid, lysine, and glycine spots. All 12 strains contained glucose, galactose, and another fast-running sugar which, on the basis of its $R_{f}$ value and color reaction with aniline-phthalate, was tentatively identified as 6-deoxytalose $(5,17)$. 
TABLE 1. Amino acids in cell walls of $G$. vaginalis

\begin{tabular}{ccccccc}
\hline \multirow{2}{*}{ Strain } & \multicolumn{5}{c}{ Cell wall amino acids ${ }^{a}$} \\
\cline { 2 - 6 } & Ala & Glu & Lys & Gly & Ser & Asp \\
\hline UQM1258 & + & + & + & + & & \\
UQM1850 & + & + & + & + & & \\
UQM1851 & + & + & + & + & & + \\
UQM1852 & + & + & + & + & + & + \\
UQM1853 & + & + & + & + & + & + \\
UQM1854 & + & + & + & + & & \\
UQM1855 & + & + & + & + & & \\
UQM1856 & + & + & + & + & & \\
UQM1857 & + & + & + & + & + & \\
UQM1858 & + & + & + & + & & + \\
UQM1859 & + & + & + & + & & + \\
UQM1860 & + & + & + & + & + & +
\end{tabular}

${ }^{a}$ Ornithine, LL-DAP, and meso/DD-DAP were not detected in any strain. Abbreviations: Ala, alanine; Glu, glutamic acid; Lys, lysine; Gly, glycine; Ser, serine; Asp, aspartic acid.

\section{DISCUSSION}

Peptidoglycan is found in the cell walls of both gram-positive and gram-negative bacteria, apart from a few halophilic bacteria (22). In the majority of cases, the gram-negative type of cell wall contains 11 to 14 amino acids, and the structure and composition of the peptidoglycan in gramnegative bacteria does not vary dramatically in different genera or species (24). The peptidoglycan of gram-positive bacteria usually contains four to six major amino acids, but the nature of these amino acids and their arrangement in the peptide side chains and cross-links vary greatly in different bacteria $(22,27)$. Recent workers have studied the correlation between peptidoglycan structure and taxonomy $(14,22)$, and peptidoglycan type is now a valuable aid in the classification of gram-positive bacteria. The nature of the dibasic amino acid in the peptidoglycan is of particular importance. Diaminopimelic acid (DAP) is the most common dibasic amino acid, and it has been found universally in gramnegative species examined so far $(22,27)$ except for certain unusual thermophilic species studied recently (18) and some strains of methane-producing bacteria (2). DAP is also found in numerous gram-positive bacteria such as species of Bacillus, Clostridium, and Corynebacterium.

The major amino acids found in the cell walls of 12 strains of $G$. vaginalis examined in the present study were alanine, glutamic acid, glycine, and lysine. Smaller amounts of serine or aspartic acid, or both, were also detected in seven of the strains. The relatively small number of amino acids found in the cell walls of these strains shows that the amino acid composition of $G$. vaginalis cell walls is that of a gram-positive bacterium. The presence of lysine and not DAP as the dibasic amino acid in the cell wall confirms that the composition is not of the gramnegative type.

Two reports have previously been published on the cell wall composition of $G$. vaginalis. Vickerstaff and Cole (25) examined the amino acid and carbohydrate composition of cell walls and the physiological characters of six presumptive $G$. vaginalis strains. The cell wall of the $G$. vaginalis type strain was found to contain galactose and 6-deoxytalose with traces of mannose and rhamnose, but the amino acid composition of the cell wall of this strain was not studied. Of the six presumptive strains of $G$. vaginalis examined, one was classified as a Corynebacteri$u m$ and two were found to be related to species of Haemophilus. The authors did not definitively identify the remaining three strains.

Criswell et al. (3) examined the amino acid content of the cell wall of the $G$. vaginalis type strain. In contrast to the results obtained in the present study, they reported that the bacterium contained a wide range of amino acids in its cell wall and concluded from parallel work on Echerichia coli and Bacillus megaterium that the cell wall was of the gram-negative type. Lysine, but not DAP, was found in the $G$. vaginalis cell wall, but this would appear to be of little significance as the authors also found lysine but no DAP in both $E$. coli and B. megaterium, in direct contrast to other workers who have examined these organisms (22).

G. vaginalis does appear to possess characteristics commonly associated with both grampositive and gram-negative bacteria $(3,4,10,13$, $21,26)$. On the basis of the results obtained in the present study, the description of the organism should be amended to state that the cell wall of $G$. vaginalis contains alanine, glutamic acid, glycine, lysine, glucose, galactose, and another sugar tentatively identified as 6-deoxytalose. The cell wall does not contain DAP and, in chemical composition, is typical of that of a gram-positive bacterium.

\section{REPRINT REQUESTS}

Address reprint requests to: Dr. J. J. Harper, Department of Microbiology, University of Queensland, St. Lucia, Brisbane, Australia.

\section{LITERATURE CITED}

1. Amies, C. R., and M. Garabedian. 1963. The bacteriology of human vaginitis. Can. J. Public Health 54:50.

2. Balch, W. E., G. E. Fox, L. J. Magrum, C. R. Woese, and R. S. Wolfe. 1979. Methanogens: reevaluation of a unique biological group. Microbiol. Rev. 43:260-296.

3. Criswell, B. S., J. H. Marston, W. A. Stenback, S. H. Black, and H. L. Gardner. 1971. Haemophilus vaginalis 594, a gram-negative organism? Can. J. Microbiol. 17:865-869. 
4. Criswell, B. S., W. A. Stenback, S. H. Black, and H. L. Gardner. 1972. Fine structure of Haemophilus vaginalis. J. Bacteriol. 109:930-932.

5. Cummins, C. S., and H. Harris. 1958. Studies on the cellwall composition and taxonomy of Actinomycetales and related groups. J. Gen. Microbiol. 18:173-189.

6. Dunkelberg, W. E., R. Skaggs, and D. S. Kellogg. 1970 Method for isolation and identification of Corynebacterium vaginale (Haemophilus vaginalis). Appl. Microbiol. 19:47-52.

7. Edmunds, P. N. 1962. The biochemical, serological and haemagglutinating reactions of Haemophilus vaginalis. $\mathbf{J}$. Pathol. Bacteriol. 83:411-422.

8. Gardner, H. L., and C. D. Dukes. 1954. New etiologic agent in nonspecific bacterial vaginitis. Science 120:853.

9. Gardner, H. L., and C. D. Dukes. 1955. Haemophilus vaginalis vaginitis. Am. J. Obstet. Gynecol. 69:962-976.

10. Greenwood, J. R., and M. J. Pickett. 1980. Transfer of Haemophilus vaginalis Gardner and Dukes to a new genus, Gardnerella: G. vaginalis (Gardner and Dukes) comb. nov. Int. J. Syst. Bacteriol. 30:170-178.

11. Haer, F. C. 1969. An introduction to chromatography on impregnated glass fiber. Ann Arbor Science Publishers Inc., Ann Arbor Mich.

12. Harper, J. J., and G. H. G. Davis. 1979. Two dimensional thin-layer chromatography for amino acid analysis of bacterial cell walls. Int. J. Syst. Bacteriol. 29:56-58.

13. Hollander, R., and W. Mannheim. 1975. Characterization of hemophilic and related bacteria by their respiratory quinones and cytochromes. Int. J. Syst. Bacteriol. 25:102-107.

14. Keddie, R. M., and G. L. Cure. 1977. The cell wall composition and distribution of free mycolic acids in named strains of coryneform bacteria and in isolates from various natural sources. J. Appl. Bacteriol. 42:229-252.

15. Leopold, S. 1953. Heretofore unde scribed organism isolat ed from the genitourinary system. U.S. Armed Forces Med. J. 4:263-266.

16. Lewis, J. F., S. M. O'Brien, U. M. Ural, and T. Burke. 1972. Corynebacterium vaginale vaginitis. Am. J. Obstet. Gynecol. 112:87-90.
17. MacLennan, A. P. 1961. Composition of the cell wall of Actinomyces bovis: the isolation of 60-deoxy-L-talose. Biochim. Biophys. Acta 48:600-601.

18. Merkel, G. J., S. S. Stapleton, and J. J. Perry. 1978. Isolation and peptidoglycan of gram-negative hydrocar bon-utilizing thermophilic bacteria. J. Gen. Microbiol 109:141-148.

19. Park, C. H., M. Fauber, and C. B. Cook. 1968. Identification of Haemophilus vaginalis. Am. J. Clin. Pathol. 49:590-593.

20. Piot, P., E. van Dyck, M. Goodfellow, and S. Falkow. 1980 A taxonomic study of Gardnerella vaginalis (Haemophilus vaginalis) Gardner and Dukes 1955. J. Gen. Microbiol. 119:373-396.

21. Reyn, A., A. Birch-Andersen, and S. P. Lapage. 1966. An electron microscope study of thin sections of Haemophilus vaginalis (Gardner and Dukes) and some possibly related species. Can. J. Microbiol. 12:1125-1136.

22. Schleifer, K. H., and O. Kandler. 1972. Peptidoglycan types of bacterial cell walls and their taxonomic implications. Bacteriol. Rev. 36:407-477.

23. Staneck, J. C., and G. D. Roberts. 1974. Simplified approach to identification of aerobic actinomycetes by thinlayer chromatography. Appl. Microbiol. 28:226-231.

24. Tipper, D. J., and A. Wright. 1979. The structure and biosynthesis of bacterial cell walls, p. 291-426. In J. R. Sokatch and L. N. Ornston (ed.), The bacteria. A treatise on structure and function, vol. 7, Mechanisms of adaption. Academic Press, Inc., New York.

25. Vickerstaff, J. M., and B. C. Cole. 1969. Characterization of Haemophilus vaginalis, Corynebacterium cervicis and related bacteria. Can. J. Microbiol. 15:587-594.

26. Weitzman, P. D. J., and D. Jones. 1975. The mode of regulation of bacterial citrate synthase as a taxonomic tool. J. Gen. Microbiol. 89:187-190.

27. Work, E. 1970. Cell walls, p. 361-418. In J. R. Norris and D. W. Ribbons (ed.), Methods in microbiology, vol. 5A. Academic Press, London.

28. Zinnemann, K., and G. C. Turner, 1963. The taxonomic position of Haemophilus vaginalis (Corynebacterium vaginale). J. Pathol. Bacteriol. 85:213-219. 